Tрансформация экосистем
Ecosystem Transformation
www.ecosysttrans.com

\title{
Invasive taxa of the genus Solidago L. in the vicinity of the city of Pskov
}

\author{
Maria A. Galkina*, Yuliya K. Vinogradova
}

N.V. Tsitsin Main Moscow Botanical Garden, Russian Academy of Sciences, Botanicheskaya str. 4, Moscow, 4127276 Russia

*mawa.galkina@gmail.com

Received: 07.02.2019

Accepted: 24.02.2019

Published online: 20.05.2019

DOI: $10.23859 /$ estr-190207

UDC 575.858:582.998.1(470)

URL: http://www.ecosysttrans.com/

publikatsii/detail_page.php?ID=116

ISSN 2619-094X Print

ISSN 2619-0931 Online

Translated by S.V. Nikolaeva
Three taxa of the genus Solidago occur in the vicinity of Pskov: $S$. virgaurea, an aboriginal species, $S$. canadensis, an invasive species of North American origin, and their hybrid $S$. $\times$ niederederi. We studied the morphology of the hybrid and parental species. The diameter of the S. $\times$ niederederi flower heads is intermediate between those in S. virgaurea and S. canadensis. The hybridogenic origin of $S$. $\times$ niederederi was demonstrated using molecular analysis of nucleotide sequences of nuclear DNA (ITS region). At present, it is not possible to unequivocally determine which of the parental species was maternal and which was paternal. By analyzing the highly variable noncoding loci of chloroplast DNA (rpl32-trnL), it can be assumed that hybridization proceeds in both directions.

Keywords: invasions, hybridization, Solidago canadensis, S. × niederederi, S. virgaurea, flower heads diameter, ITS region, chloroplast loci rpl32-trnL.

Galkina, M.A., Vinogradova, Yu.K., 2019. Invasive taxa of the genus Solidago L. in the vicinity of the city of Pskov. Ecosystem Transformation 2 (2), 12-18.

\section{Introduction}

Invasions of alien species lead to the depletion of the flora of vast territories and may cause economic damage (McGeoch et al., 2010; Vinogradova et al., 2010). The North American species Solidago canadensis (Linnaeus, 1753) is among the top one hundred most aggressive invasive species in Russia (Vinogradova et al., 2015). Indeed, when a foreign species is becoming naturalized, there is an interaction with representatives of the native flora, which can also lead to the formation of hybrids. There is a hypothesis that in secondary ranges, the intensity of hybridization processes increases (Ellstrand and Schierenbeck, 2000; Elton, 1958). Moreover, hybrids may be more adapted to the conditions of the new environment than their parental taxa (Abbott et al., 2003; Bleeker et al., 2007; Zalapa et al., 2009). In European Russia, hybrids make up $10 \%$ of the total number of invasive species (Vinogradova and
Mayorov, 2015). Parent species of the European hybrid S. × niederederi (Khek, 1905) are S. canadensis and S. virgaurea (Linnaeus, 1753). Populations of S. $\times$ niederederi have been recorded in Austria, Great Britain, Lithuania and Poland (Pagitz, 2016), and over the past decades it has significantly expanded its range (Karpavičiené and Radušiené, 2016; Pliszko and Zając, 2016). In our previous studies using the ISSR method, it was found that plants collected in European Russia, identified using morphological features as $S$. × niederederi, are highly likely to be of hybrid origin (Vinogradova and Galkina, 2019), however that can only be confirmed by analyzing the nucleotide DNA sequences of the presumed hybrids and parents. We aimed to study the features of Solidago hybrids in northwestern Russia, since the most numerous recent records of $S$. $\times$ niederederi are from northeastern Europe, to which the Pskov region is the most closely located region of Russia. 
Previously, based on an analysis of the highly variable non-coding chloroplast rpl32-trnL locus, Pliszko and Zalewska-Gałosh (2016) found that hybridization between $S$. canadensis and $S$. virgaurea can go both ways, and both species can be either maternal or paternal plants. We aim to determine which situation, with respect to the parental taxa, is observed in the Pskov populations of these species.

\section{Materials and methods}

The diameter and length of the flower heads were measured using a Keyence VHX-1000 digital microscope. For each of the three taxa, we measured 30 flower heads from plants collected in the Pskov region (Pskov district, vicinity of Pskov, an unused field near a highway). Statistical data were processed in the PAST 3 program.
DNA extraction was carried out using the CTAB method (Rogers and Bendich, 1985) from herbarium material collected in the Pskov and Moscow regions (Table 1). In the Moscow region, representatives of the parental species were collected at two sites, in the Losiny Ostrov National Park (in a pine forest with spruce and birch) and in the vicinity of the village of Chudinovo in the Chekhov district (an unused field). These additional samples were used to more accurately assess the polymorphism of the invasive species $S$. canadensis and the native $S$. virgaurea in European Russia, as well as to control for incorrect interpretation of the results of the analysis of chloroplast DNA loci to determine the maternal species.

Polymerase chain reaction (PCR) was performed in a DNA Engine Dyad Peltier Thermal Cycler amplifier (Biorad, USA). For the nuclear region of ITS, the

Table 1. Samples of various taxa of the genus Solidago L. (presumed $S$. $\times$ niederederi hybrid and parental species) used for molecular genetic analysis.

\begin{tabular}{|c|c|c|c|c|c|}
\hline $\begin{array}{l}\text { Sample } \\
\text { number }\end{array}$ & $\begin{array}{l}\text { The number } \\
\text { of the ITS } \\
\text { sequence in } \\
\text { GenBank }\end{array}$ & $\begin{array}{l}\text { The number } \\
\text { of the rpl32- } \\
\text { trnL locus in } \\
\text { GenBank }\end{array}$ & Taxon & $\begin{array}{l}\text { Collection site } \\
\text { and habitat }\end{array}$ & $\begin{array}{l}\text { Collection } \\
\text { year }\end{array}$ \\
\hline v_1a & MK491849 & MK474079 & & \multirow{9}{*}{$\begin{array}{l}\text { Pskov region, Pskov } \\
\text { district, vicinity of Pskov, } \\
\text { idle field, N } 57.80^{\circ} \text {, } \\
\text { E } 28.25^{\circ}\end{array}$} & \multirow{9}{*}{2018} \\
\hline$v_{-} 1 b$ & MK491850 & MK474080 & S. virgaurea & & \\
\hline$v_{-} 1 c$ & MK491851 & MK474081 & & & \\
\hline n_2a & MK491852 & MK474082 & & & \\
\hline$n \_2 b$ & MK491853 & MK474083 & S. $\times$ niederederi & & \\
\hline n_2c & - & MK474084 & & & \\
\hline c_3a & MK491854 & MK474085 & \multirow{3}{*}{ S. canadensis } & & \\
\hline c_3b & MK491855 & MK474086 & & & \\
\hline c_3c & MK491856 & MK474087 & & & \\
\hline v_4 & - & MK474088 & S. virgaurea & \multirow{3}{*}{$\begin{array}{l}\text { Moscow region, Chekhov } \\
\text { district, near the village } \\
\text { of Chudinovo, idle field, } \\
\text { N } 55.1^{\circ} \text {, E } 37.5^{\circ}\end{array}$} & \multirow{3}{*}{2018} \\
\hline c_5a & MK491857 & MK474090 & \multirow[t]{2}{*}{ S. canadensis } & & \\
\hline c_5b & - & MK474089 & & & \\
\hline v_6a & MK491858 & - & & \multirow{2}{*}{$\begin{array}{l}\text { Moscow region, "Losiny } \\
\text { Ostrov" National Park, } \\
\text { pine forest, N } 55.89^{\circ} \text {, } \\
\text { E } 37.77^{\circ}\end{array}$} & \multirow[b]{2}{*}{2014} \\
\hline v_6b & MK491859 & - & S. virgaurea & & \\
\hline
\end{tabular}


primers nnc18s 10 (forward) and c26A (reverse) were used at an annealing temperature of $50{ }^{\circ} \mathrm{C}$. For the chloroplast locus rpl32-trnL, primers rpl32F (forward) and trnL UAG (reverse) were used at an annealing temperature of 0.3 to $65{ }^{\circ} \mathrm{C}$ according to J. Shaw et al.'s (2007) method. The same PCR conditions were adopted for another chloroplast locus, trnL-trnF (primers $\mathrm{C}$ and f). The PCR products were purified for sequencing using the ammonium/Ethanol mixture protocol. Determination of nucleotide DNA sequences was carried out using an automatic sequencer in ZAO "Syntol". The nucleotide sequences were further processed using the BioEdit software. The data obtained were deposited into the GenBank database (https://www.ncbi.nlm.nih.gov/nuccore), where these nucleotide sequences can be found using their assigned numbers (Table 1 ).

\section{Results and discussion}

The main difference between $S$. $\times$ niederederi and his parents is the structure of the shoot systems (mainly the structure of the inflorescence, Fig. 1). In

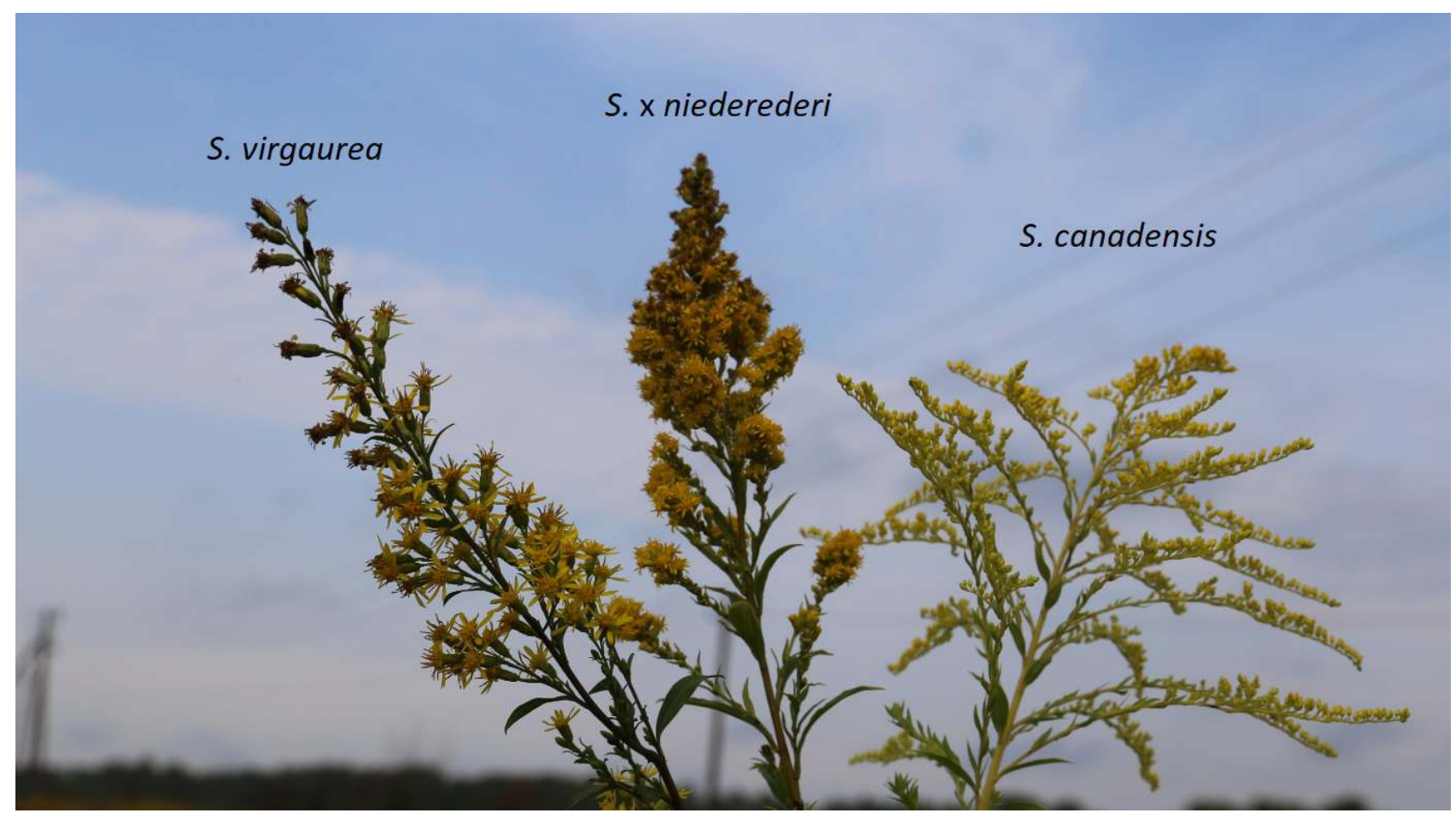

Fig. 1. Flower head morphology of Solidago $\times$ niederederi and its parental species.
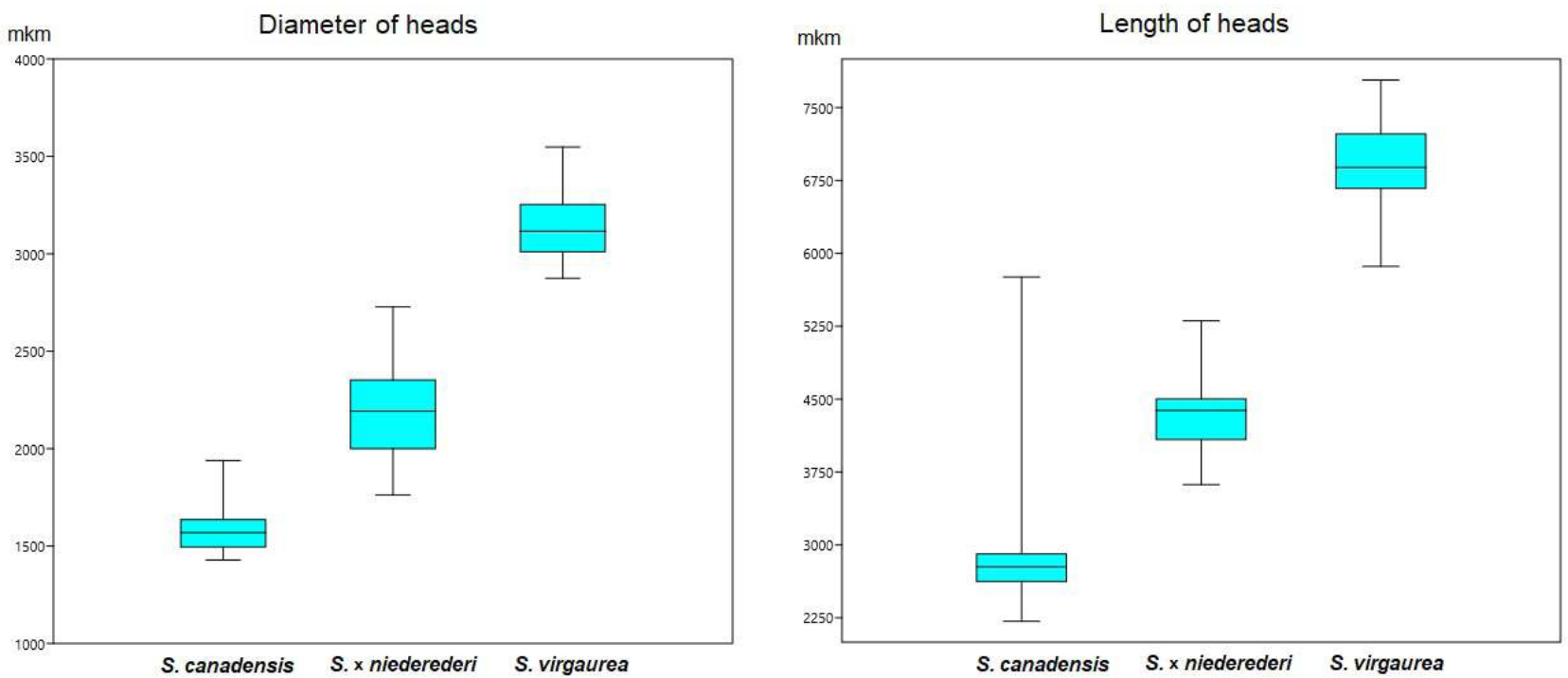

Fig. 2. Parameters of flower heads of Solidago $\times$ niederederi and its parental species: quartiles (1st and 3rd), median, maximum and minimum values are indicated. 


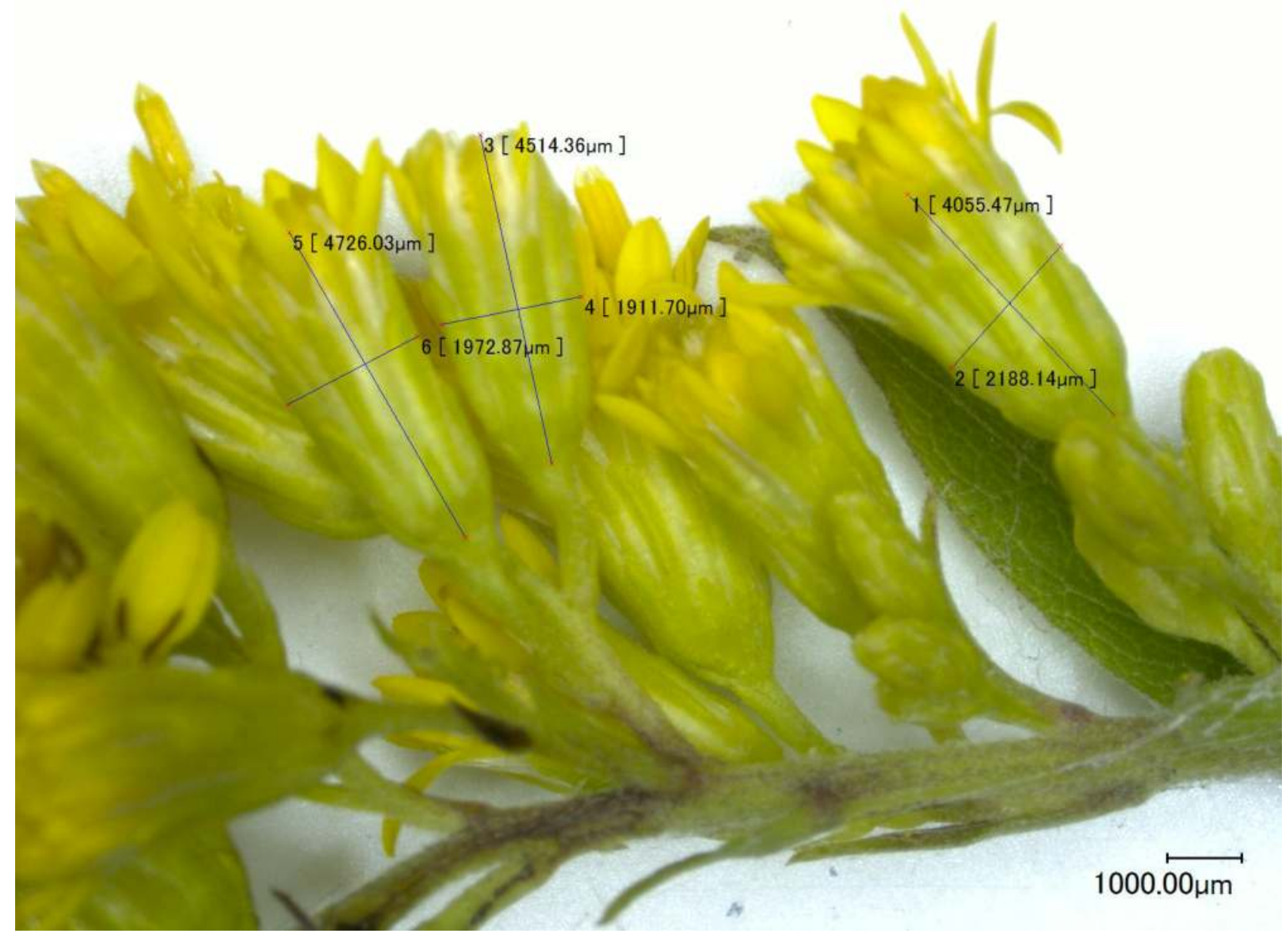

Fig. 3. Flower heads of Solidago $\times$ niederederi with a measurement scheme.

S. canadensis, numerous flower heads are assembled in loose panicles; in $S$. $\times$ niederederi flower heads are fewer and they are compressed in a compressed panicle, whereas in S. virgaurea the number of flower heads is the lowest, and the branches of the panicle are so short that the inflorescence resembles a spike. The sizes of the flower heads are also different (Fig. 2). The flower heads of S. $\times$ niederederi (Fig. 3) are oval in shape and are intermediate in diameter between the parental species - $2201 \pm 45 \mu \mathrm{m}$ (mean \pm standard error) with a maximum spread from 1762 to $2728 \mu \mathrm{m}$, whereas for $S$ virgaurea and $S$. canadensis these values are $3132 \pm 30 \mu \mathrm{m}$ (2874-3548 $\mu \mathrm{m})$ and $1591 \pm 22 \mu \mathrm{m}(1428-1939 \mu \mathrm{m})$, respectively. As for the length of the flower heads, the Pskov representatives of $S$. $\times$ niederederi cannot be clearly distinguished from $S$. canadensis using this character, due to its high variability in S. canadensis. However, according to mean lengths of flower heads, the hybrid also occupies an intermediate position between the parental species (Fig. 2). The shoots of $S$. canadensis and $S$. $\times$ niederederi are pubescent, whereas the shoots of $S$. virgaurea are bare, shiny, and sometimes reddish in color. The leaves of $S$. $\times$ niederederi in the middle part of the shoot are
Table 2. ITS polymorphism for the Solidago $\times$ niederederi hybrid and parental species. The nucleotides are coded using IUPAC nomenclature.

\begin{tabular}{|c|c|c|c|c|}
\hline \multirow{2}{*}{$\begin{array}{c}\text { Sample } \\
\text { no. }\end{array}$} & \multicolumn{4}{|c|}{ Position in alignment } \\
\hline & 384 & 431 & 508 & 549 \\
\hline v_1a & $\bar{T}$ & A & C & $\mathrm{A}$ \\
\hline$v_{-} 1 b$ & $\mathrm{~T}$ & A & C & A \\
\hline v_1c & $\mathrm{T}$ & A & C & A \\
\hline n_2a & $Y$ & M & $Y$ & $R$ \\
\hline n_2b & Y & $M$ & $\mathrm{Y}$ & $\mathrm{R}$ \\
\hline c_3a & C & C & $\mathrm{T}$ & $G$ \\
\hline c_3b & C & C & $\mathrm{T}$ & $G$ \\
\hline c_3c & $Y$ & $M$ & $\mathrm{~T}$ & $\mathrm{R}$ \\
\hline c $5 a$ & C & C & $\mathrm{T}$ & $G$ \\
\hline v $6 a$ & $\mathrm{~T}$ & A & C & A \\
\hline$\vee 6 b$ & $\mathrm{~T}$ & A & C & A \\
\hline
\end{tabular}




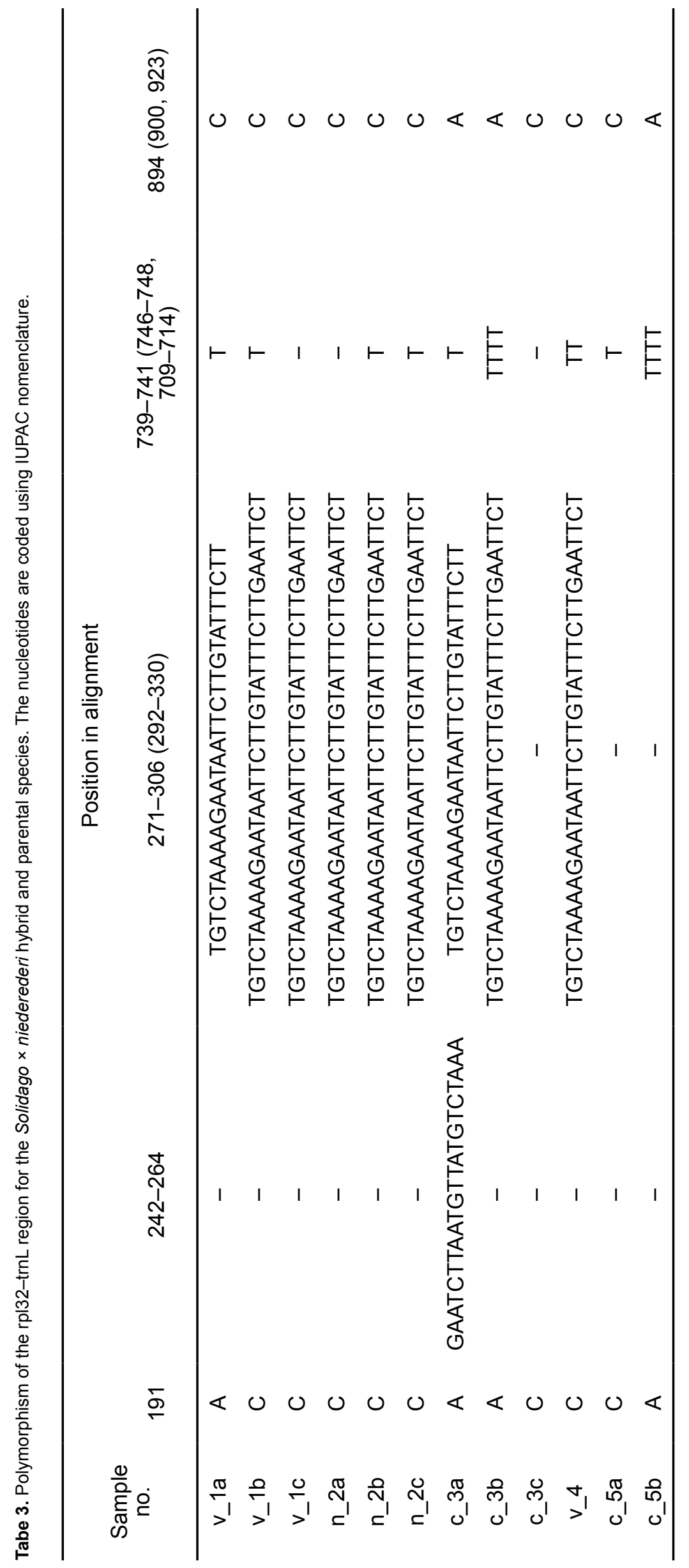


linear-lanceolate, dentate along the edge, with three distinct veins (as in S. canadensis), and in the basal part of the shoot are large, ovate, with a reticulated venation (as in S. virgaurea).

To confirm the hybridogenic origin of the S. $\times$ niederederi population in the vicinity of Pskov, the nucleotide sequences of the nuclear and chloroplast DNA of Pskov individuals (both parental and hybridogenic species), as well as individuals of the parental species from the Moscow region, were analyzed. The analysis of the ITS region showed that in all cases of nucleotide substitutions differentiating S. virgaurea and $S$. canadensis, $S . \times$ niederederi had ambiguous readings (Table 2), indicating heterozygosity, which confirms the hybrid origin of individuals from this population. One of the samples of $S$. canadensis (c $3 c$ ) in three cases of four of the nucleotide substitutions showed heterozygosity, although morphologically this sample did not differ from other individuals of $S$. canadensis, which indicates the presence of introgressive hybridization within the genus Solidago. This sample is probably a backcross (i.e., the result of crossing $S$. $\times$ niederederi with the parental species $S$. canadensis).

Analysis of the highly variable intergenic spacer rpl32-trnL did not produce an unambiguous answer of which of the species is maternal for $S$. $\times$ niederederi, and which is paternal. Unlike the results obtained by A. Pliszko and Z. Zalewska-Galosh (2016), our $S$. canadensis samples show higher variability of this locus of chloroplast DNA. For instance, sample c_3a from the Pskov region has a DNA fragment, which is absent in other representatives of $S$. canadensis not only from Pskov, but also from the Moscow region (242-264 nucleotides, Table 3). The locus in positions 271-306 in the alignment of our sequences (292-330 for sample c_3a, Table 3) and differentiating the parental species in Polish populations (Pliszko and Zalewska-Gałosh, 2016) may differ not only in $S$. × niederederi but in both parental species. The analysis of another noncoding region of the chloroplast DNA (trnL-trnF), also did provide us with an answer, as all the samples under study turned out to be identical in this region. Based on the data obtained, we can only assume that in the Pskov population hybridization proceeds in both directions, but there is also the probability that only one species can be maternal and the other paternal, and a search for other, more prominently variable regions of chloroplast DNA is required. This is a subject for further study.

\section{Conclusions}

In the unused field studied in the vicinity of Pskov, three taxa occur together: $S$. canadensis (an invasive species of North American origin), S. virgaurea (a native species) and their hybrid $S$. $\times$ niederederi. This was confirmed by analyzing the ITS sequences of nu- clear DNA. As both parents, especially S. canadensis, are relatively polymorphic taxa, it is not possible to unequivocally determine which of the two species is maternal, and which is paternal. The presence of introgressive hybridization within the genus Solidago is highly probable.

\section{Acknowledgments}

The study was performed within the framework of the State Contract of the GBS of the Russian Academy of Sciences (no. 19-119012390082-6) with partial support from the Russian Foundation for Basic Research (project no. 18-04-00411).

\section{References}

Abbott, R.J., James, J.K., Milne, R.I., Giles, A.C.M., 2003. Plant introduction, hybridization and gene flow. Philosophical Transactions of the Royal Society $358,1123-1132$.

Bleeker, W., Schmitz, U., Ristow, M., 2007. Interspecific hybridization between alien and native plant species in Germany and its consequences for native biodiversity. Biological Conservation 137 (2), 248-253.

Ellstrand, N.C., Shierenbeck, K.A., 2000. Hybridization as a stimulus for the evolution of invasiveness in plants? Proceedings of the American Society of Naturalists 97 (13), 7043-7050.

Elton, C.S., 1958. The ecology of invasions by animals and plants. Methuen, London, Great Britain, $212 \mathrm{p}$.

Karpavičiené, B., Radušiené, J., 2016. Morphological and anatomical characterization of Solidago $\times$ niederederi and other sympatric Solidago species. Weed Science 64 (1), 61-70.

McGeoch, M.A., Butchart, C.H.M., Spear, D. et al., 2010. Global indicators of biological invasion: species numbers, biodiversity impact and policy responses. Diversity and Distributions 16, 95-108.

NCBI. Nucleotide. The Nucleotide database is a collection of sequences from several sources, including GenBank, RefSeq, TPA and PDB. Genome, gene and transcript sequence data provide the foundation for biomedical research and discovery. Web page. URL: https://www.ncbi.nlm.nih.gov/ nuccore (accessed: 28.02.2019).

Pagitz, K., 2016. Solidago $\times$ niederederi (S. canadensis $\times$ S. virgaurea ssp. virgaurea) in the Eastern Alps. Abstracts of Conference "Neobiota 2016". Foundation faune-flore, Vianden, Luxembourg, 194. 
Pliszko, A., Zając, M., 2016. Current and potential distribution of Solidago $\times$ niederederi (Asteraceae) in Poland. Abstracts of Conference "Neobiota 2016". Foundation faune-flore, Vianden, Luxembourg, 163.

Pliszko, A., Zalewska-Gałosh, J., 2016. Molecular evidence for hybridization between invasive Solidago canadensis and native S. virgaurea. Biological Invasions 18, 3103-3108.

Rogers, S.O., Bendich, A.J., 1985. Extraction of DNA from milligram amounts of fresh, herbarium and mummified plant tissues. Plant Molecular Biology 5, 69-76.

Shaw, J., Lickey, E.B., Schilling, E.E., Small, R.L., 2007. Comparison of whole chloroplast genome sequences to choose noncoding regions for phylogenetic studies in Angiosperms: the tortoise and the hare III. American Journal of Botany 94 (3), 275-288.

Vinogradova, Yu.K., Galkina, M.A., 2019. Gibridizatsiya kak faktor invazionnoy aktivnosti chuzherodnyh vidov zolotarnika (Solidago) [Hybridization as a factor of invasive activity alien species of Goldenrods (Solidago L.)]. Zhurnal obshey biologii [Journal of General Biology] 80 (1), 43-56. (In Russian).
Vinogradova, Yu.K., Mayorov, S.R., 2015. Dlitelnost lag-fazy kak otrazhenie mikroevolutsii rasteniy vo vtorichnom areale [Period of lag-phase as mirror of plant microevolution in the secondary distribution range]. Materialy XIII Moskovskogo soveshaniya po filogenii rasteniy "50 let bez K.I. Meyera" [Abstracts of XIII Moscow conference about Plant Phylogeny "50 years without K.I. Meyer"]. Max Press, Moscow, Russia, 70-74. (In Russian).

Vinogradova, Yu. K., Mayorov, S.R., Khorun, L.V., 2010. Chernaya kniga flory Sredney Rossii [The Black Book of Flora of Middle Russia]. Geos, Moscow, Russia, 512 p. (In Russian).

Vinogradova, Yu. K., Abramova, L.M., Akatova, T.V. et al, 2015. "Chernaya sotnya" invazionnyh rasteniy Rossii ["Black hundred" of invasive plants of Russia]. Informatsionny bulleten soveta botanicheskih sadov stran SNG [Informational Bulletin of the Council of Botanical Gardens of CIS countries] 4 (27), 85-89. (In Russian).

Zalapa, J.E., Brunet, J., Guries, R.P., 2009. Patterns of hybridization and introgression between invasive Ulmus pumila (Ulmaceae) and native $U$. rubra. American Journal of Botany 96, 1116-1128. 